\title{
Emergency treatment of complicated incisional hernias: a case study
}

Francesco La Mura*, Roberto Cirocchi, Eriberto Farinella, Umberto Morelli, Vincenzo Napolitano, Lorenzo Cattorini, Alessandro Spizzirri, Barbara Rossetti, Pamela Delmonaco, Carla Migliaccio, Diego Milani, Piero Covarelli, Carlo Boselli, Giuseppe Noya and Francesco Sciannameo

Address: General Surgical Unit, St. Maria Hospital, Terni (TR), University of Perugia, Italy

Email: Francesco La Mura* - doctorfrank81@hotmail.it; Roberto Cirocchi - cirocchiroberto@yahoo.fr;

Eriberto Farinella - eriberto.far@gmail.com; Umberto Morelli - umorelli@libero.it; Vincenzo Napolitano - e_napolitano@libero.it;

Lorenzo Cattorini - Cremesys@excite.it; Alessandro Spizzirri - aspizzirri@yahoo.it; Barbara Rossetti - babyross@yahoo.it;

Pamela Delmonaco - pamela.delmonaco@alice.it; Carla Migliaccio - carlamigliaccio@gmail.com; Diego Milani - diegomilani@yahoo.it;

Piero Covarelli - piero.covarelli@med.unipg.it; Carlo Boselli - carloboselli@yahoo.it; Giuseppe Noya - gnoya@unipg.it;

Francesco Sciannameo - francescosciannameo@unipg.it

* Corresponding author

Published: 17 December 2009

Received: 3 January 2009

Annals of Surgical Innovation and Research 2009, 3:15 doi:10.1186/1750-1164-3-15

Accepted: 17 December 2009

This article is available from: http://www.asir-journal.com/content/3/I/I5

(C) 2009 La Mura et al; licensee BioMed Central Ltd.

This is an Open Access article distributed under the terms of the Creative Commons Attribution License (http://creativecommons.org/licenses/by/2.0),

which permits unrestricted use, distribution, and reproduction in any medium, provided the original work is properly cited.

\begin{abstract}
Background: The emergency treatment of incisional hernias is infrequent but it can be complicated with strangulation or obstruction and in some cases the surgical approach may also include an intestinal resection with the possibility of peritoneal contamination. Our study aims at reporting our experience in the emergency treatment of complicated incisional hernias.

Methods: Since January 1999 till July 2008, 89 patients (55 males and 34 females) were treated for complicated incisional hernias in emergency. The patients were divided in two groups: Group I consisting of 33 patients that were treated with prosthesis apposition and Group II, consisting of 56 patients that were treated by performing a direct abdominal wall muscles suture.

Results: All the patients underwent a 6-month follow up; we noticed 9 recurrences $(9 / 56,16 \%)$ in the patients treated with direct abdominal wall muscles suture and I recurrence $(I / 33,3 \%)$ in the group of patients treated with the prosthesis apposition.

Conclusions: According to our experience, the emergency treatment of complicated incisional hernias through prosthesis apposition is always feasible and ensures less post-operative complications (16\% vs $21,2 \%$ ) and recurrences ( $3 \%$ vs $16 \%$ ) compared to the patients treated with direct muscular suture.
\end{abstract}

\section{Background}

Repair of abdominal wall hernia represents the most common group of operatios performed by general surgeons all around the world. Incisional hernia is a serious complication after abdominal surgery which occurs in $11-23 \%$ of laparotomies [1]. 
In 2003 it was estimated that over 100,000 ventral incisional hernia repairs were performed in the US. Risk factors for incisional hernia formation and preventive strategies are not clearly defined, but according to data from literature, significant demographic factors influencing incisional hernia incidence are age ( $>45$ years) and male gender. Preoperative anaemia $(\mathrm{Hb}<100 \mathrm{~g} / \mathrm{l})$ and BMI $>25$, associated with previous laparotomies and postoperative catecholamin-therapy also seem to play an important role [2]. The tension-free repair is one of the key concepts in hernia surgery. The use of a mesh prosthesis decreases the recurrence rates, particularly for inguinal and incisional hernias. Recently, the laparoscopic approach extended the options and approaches for repairing the fascial defect.

The emergency treatment of incisional hernias is not frequent [3], and its technical approach can be different from the elective one, both for the septic conditions in which the emergency treatment is usually performed and for the patients' age which can lead to several technical difficulties. As an emergency, it often occurs in elderly patients with voluminous hernias complicated with strangulation or obstruction [4]. In some of these cases the surgical approach may also include an intestinal resection, with the possibility of peritoneal contamination [5]. This study aims at reporting our experience in the emergency treatment of complicated incisional hernias, analysing the results obtained with the employment of synthetic prosthesis versus the open surgical repair.

\section{Materials and methods}

We performed a clinical study by revising clinical notes, through which we evaluated the different treatments of patients with complicated incisional hernias. All the patients whose hernia were only an attendant pathology and did not represent itself the cause for an emergency surgical treatment, were excluded fom the trial.

Since January 2001 till July 2008, 89 patients (55 males and 34 females) were treated for complicated incisional hernias in emergency. We divided the patients in two different groups. The patients treated with prosthesis apposition (Group I) were 33 (24 males and 9 females) while 56 patients (Group II) (31 males and 25 females) were treated by performing a direct abdominal wall muscles suture. Five of these patients $(8,9 \%)$ had such voluminous incisional hernias that they could not be treated by carrying out a direct abdominal wall muscles suture (Table 1).

\section{Results}

As concerns the group treated with the apposition of prosthesis (Group I), obstruction with no possibility of reduction occurred in 27 cases; in these cases we performed an adhesiolisis and a greater omentum resection (14 patients) which eased the abdominal replacement of the ileal ansae, being the omentum often inflamed, thickened and fibrous. In the remaining 6 cases, strangulation was the reason for an emergency treatment; in these cases we performed a resection of the necrotic ileum and the intestinal continuity was restored by carrying out a mechanic suture. Strangulation occurred in those patients whose incisional hernias had a narrow neck. We registered 7 complications; 4 parcellar cutaneous necrosis, 2 hematomas and 1 wound suppuration (Table 2).

The surgical technique performed for Group I patients, was carried out through the apposition of polypropylene prosthesis which was placed between the posterior rectus wall and the anterior wall of the rectus sheath. The prosthesis was fixed by non-absorbable interrupted stitches which were sequentially placed through the aponeurosis, the prosthetis, back into the prosthetis and finally again through the aponeurosis, approximately $0.5 \mathrm{~cm}$ by the entrance point. The suture must be performed at least 2 $\mathrm{cm}$ far from the hernia edge, in a totally sane tissue. On the contrary the patients with voluminous incisional hernias were treated with a PTFE mesh (polytetrafluoroethylene) which was placed intraperitoneally, in contact with the abdominal viscera. The employment of PTFE allows the reduction of viscero-parietal adhesions and the constitution of a stronger abdominal wall.

In the patients treated with a direct abdominal wall muscles suture (Group II) we carried out an adhesiolysis and a greater omentum resection in 41 patients. In 15 cases we performed a resection of the necrotic ileum followed by a mechanic suture. We registered 24 complications; 7 par-

Table I: Emergency treatment of complicated incisional hernias

\begin{tabular}{lcc}
\hline & $\begin{array}{c}\text { Prosthesis apposition } \\
\text { (Group I) }\end{array}$ & $\begin{array}{c}\text { Direct abdominal wall muscles suture } \\
\text { (Group II) }\end{array}$ \\
\hline Patients treated & 33 & 56 \\
\hline Omentum resections & 14 & 41 \\
\hline Intestinal resections & 6 & 15 \\
\hline
\end{tabular}


Table 2: Complications

\begin{tabular}{lcc}
\hline & $\begin{array}{c}\text { Prosthesis apposition } \\
\text { (Group I) }\end{array}$ & $\begin{array}{c}\text { Direct abdominal wall muscles suture } \\
\text { (Group II) }\end{array}$ \\
\hline Total complications & $7(21 \%)$ & $24(43 \%)$ \\
\hline Parcellar cutaneous necrosis & $4(57 \%)$ & $7(29 \%)$ \\
\hline Hematomas & $2(29 \%)$ & $6(25 \%)$ \\
\hline Wound suppuration & $1(14 \%)$ & $11(46 \%)$ \\
\hline
\end{tabular}

cellar cutaneous necrosis, 6 hematomas and 11 wound suppurations (Table 2).

All the patients underwent a 6-month follow up; we noticed 9 recurrences $(9 / 56,16 \%)$ in the patients treated with direct abdominal wall muscles suture and 1 recurrence $(1 / 33,3 \%)$ in the group of patients treated with the prostesis apposition (Table 3$)$.

\section{Discussion}

Incisional hernias can range in size from very small to large and complex ones and appear as a bulge by the area of a previous surgical scar. Nearly any prior abdominal operation can develop an incisional hernia, however the most frequent site is along incisions running down from the breastbone to the pubic area. These hernias may occur after large surgeries such as intestinal or vascular surgery, but also after an appendectomy or even through the small scar of a laparoscopy wound. Surgical repair of incisional hernias is usually recommended, as they can become a medical or surgical emergency.

An incisional hernia can be defined as complicated when the involved structures undergo worsening conditions. Particularly, the concerned structures may be described as follows:

1) Cutaneous: large and thin scars, cutaneous atrophy and eczemas, suppurative flogosis, fistulae.

2) Hernial sac: multiple sacs, fibrous septa, sac thickening and adhesions.

3) Visceral: chronic incarceration, obstruction, strangulation, ileum and colonic torsion with progressive damage up to gangrene; greater omentum involvement, mesenteritis and perivisceritis.

The frequency of complicated incisional hernias varies from 10 to $40 \%$. The most frequent complications are incarceration, obstruction and strangulation [6].

There are two main factors for the pathogeneses of these complications: the hernial orifice rigidity and the presence of tenacious adhesions between the hernial sac and its content or between the sac and the surrounding tissues.

The formation of viscero-visceral and viscero-parietal bridles is the necessary condition for the production of strangulation: the intestinal loop contained into the sac is firstly affected by a transit alteration and later on by circulatory disturbance.

The strangulated intestinal tract rapidly goes towards congestion, edema and turgor caused by a disturbance of venous circulation which is followed by the formation of trasudate into the intestinal loop entrapped into the hernial sac; the intestinal wall goes towards progressive modifications up to necrosis and perforation. The omentum can be involved in the strangulation process; in such case the affected part adheres to the hernial sac and turns into a fibrous tissue. In case of strangulation, the symptoms will be those of a typical intestinal occlusion or subocclusion, depending on the elapsed time and the single material cause, although the synthomatology can sometimes be hard to define; for instance, in obese abdomens it is not easy to recognize the strangulation of small laparoceles.

The emergency surgical treatment for complicated incisional hernias, besides the problems given by the lack of

Table 3: Recurrences

\begin{tabular}{lcc}
\hline & $\begin{array}{c}\text { Prosthesis apposition } \\
\text { (Group I) }\end{array}$ & $\begin{array}{c}\text { Direct abdominal wall muscles suture } \\
\text { (Group II) }\end{array}$ \\
\hline Recurrences & I (3\%) & $9(16 \%)$ \\
\hline
\end{tabular}


intestinal preparation, shows a higher morbidity also due to the development of an acute respiratory failure; this is caused by the abdominal reduction of the herniated viscera which causes an increase of endoabdominal pressure pushing up the diaphragm [7].

Since the newly formed subcutaneous cavity resulting from the hernia reduction can be origin of haematic collections formation associated with a frequent necrosis of the cutaneous rims, we suggest to perform a cutaneous and subcutaneous resection in order to avoid both complications. Furthermore in all the patients we normally place one or two subcutaneous Jackson-Pratt suction drainages.

At the moment the most frequent treatment of voluminous incisional hernias is performed through the use of synthetic prosthesis, which allows the abdominal wall reconstruction according to the "tension free" technique.

The prosthesis is to be placed between the peritoneum and the posterior surface of the rectus abdominis muscles $[8,9]$ or between the posterior surface of the rectus abdominis muscles and their posterior sheath [10]. In both cases the prosthesis apposition allows a strength discharge upon the abdominal wall circumference; moreover, the overlap of the muscle to the prosthesis (properitoneal technique) allows a wider distribution surface of tension strengths. In order to avoid a prosthesis dislocation, it is necessary to fix it to the abdominal wall by non-absorbable interrupted stitches (prolene). The prosthesis must be considerably wider than the parietal breach, so that the endoabdominal pressure might ease its adhesion to the abdominal wall. The anterior rectus muscles sheath is closed by a continuous non-absorbable suture. When it is not possible to suture the abdominal wall because of a massive tissutal loss, we place a PTFE prosthesis in contact with the viscera and we suture it to the muscle sheaths $[11,12]$. PTFE avoids visceral adhesions, assuring this material to be used in properitoneal locations for voluminous incisional hernias when it is not possible to perform a direct peritoneal suture; it also lowers the infections incidence and causes only a weak foreign body reaction [13-19] (Appendix 1).

The described techniques performed in emergency do not show a higher incidence of complications (fistulisation, hematomas and wound dehiscence) compared to elective surgery $[20,21]$; also according to our experience, the emergency treatment of complicated incisional hernias appears to be feasible, both in terms of post-operative complications and recurrences.

\section{Conclusions}

According to our experience, the emergency treatment of complicated incisional hernias through prosthesis apposi- tion is always feasible and ensures less post-operative complications ( $21 \%$ vs $43 \%)$ and recurrences (3\% vs $16 \%$ ) compared to the patients treated with direct muscular suture.

The technical approach in emergency is correct when considering the clinical conditions of the patient, the size of the hernia and each eventual complication; such a dealing will minimize the complication rate and make it comparable to the one achieved with elective practice. Furthermore, synthetic prosthesis allows defects of any size to be repaired without tension and with a lower recurrence rate, providing an added support to the weak abdominal wall.

\section{Competing interests}

The authors declare that they have no competing interests.

\section{Consent section}

All the patients were informed that their clinical history would be used for a study. All of them signed a personal data treatment consent. No image was used.

\section{Authors' contributions}

FL cooperated in writing the article and translated it into English

RC drafted the article

EF checked the numbers and percentages

UM updated the references

VN made the tables

LC formatted the article

AS searched for the references

BR collected patients' data

PD chose the most useful and interesting articles in literature about the field

CM searched for the references

DM collected the patients' consent

PC gave some language suggestions

CB formatted the references

GN supervised the article production

FS allowed the collection of the patients' data and supervised the whole work making 
All the authors read and approved the final version of the manuscript

\section{Appendix I}

Features of PTFE prosthesis:

Low infections incidence

Absorbability by connective tissues

Low incidence of adhesions

Weak foreign body reaction

\section{References}

I. Dur AH, den Hartog D, Tuinebreijer WE, Kreis RW, Lange JF: Low recurrence rate of a two-layered closure repair for primary and recurrent midline incisional hernia without mesh. Hernia 2009, 13(4):42I-6. Epub 2009 Mar 19

2. Höer J, Lawong G, Klinge U, Schumpelick V: Factors influencing the development of incisional hernia. A retrospective study of 2,983 laparotomy patients over a period of 10 years. Chirurg 2002, 73(5):474-80.

3. Hornat P, Le Du J, Chaperon J, Lavenac G, Mainbrini A: Traitement des eventrations abdominales post-operatories par prothese resorbable. J Chir 1996, I3(3):3II.

4. Trivellini G: The emergency treatment of voluminous laparoceles. G Chir 1993, I 4(7):337-43.

5. Trivellini G, Danelli PG, Cortese L, Magri R, Meroni M: Trattamento delle ampie perdite di sostanza reale della parete addominale, nostra esperienza. Arch. ed Atti $93^{\circ}$ Congr. Soc. It. Chir Firenze, Ottobre 1991.

6. Gargiulo A, Grifi M, Zoppe C: Laparoceli complicati. Arch Ed Atti S.I.C, Roma 1981:1184.

7. Rives J, Lardennois B, Pire JC, Hobow J: large incisional hernias. The importance of flail abdomen and of subsequent respiratory disorders. Chirurgie 1973, 99(8):547-63.

8. Stoppa R, Henry X, Canarelli JP, Largueche S, Verhaeghe P, Abet D, Ratsivalaka R: Indications for selective operative procedures in the treatment of post-operative eventrations of the anterolateral abdominal wall. Chirurgie 1979, 105(4):276-86.

9. Stoppa R, Henry X, Odimba E, Verhaeghe P, Largueche S, Myon Y: Dacron tulle prosthesis and biological glue in the surgical treatment of incisional hernias. Nuov Presse Med 1980, 9(46):354I-5.

10. Rives J, Pire JC, Flament JB, Palot JP, Body C: Treatment of large eventrations. New therapeutic indications apropos of 322, cases. Chirurgie 1985, I I I(3):215-25.

II. Trivellini G, Danelli PG, Cortese L, Sollini A, Rossi R: L'impiego di due protesi in contemporanea nella riparazione delle grosse perdite di sostanza reale della parete addominale. Chirurgia 1991, 4(II):60I-6.

12. Temudon T, Siadati M, Sarr M: Repair of complex giant or recurrent ventral hernia by using tension-free intraparietal prosthetic mesh (Stoppa technique): Lessons learned from our initial experience. Surgery 1996, I 20(4):738-44.

13. Apuzzo A, Barbieri A, De Marco G, D'Onofrio G, Marchese P, Pontillo P, Russo S, Scolastico F: L'evoluzione delle laparoalloplastiche in PTFE (Gore-Tex). La nostra esperienza. Atti GREPA Napoli 1997:SI5.

14. Garavello A, Tuccimei U, Sadighi A, Belardi A, Remedi M, Antonellis $D$ : The surgery of laparoceles. The postoperative complications. Minerva Chir 1997, 52(5):557-63.

15. Romeo G: L'impiego di protesi in PTFE nel trattamento chirurgico dei laparoceli. Atti GREPA Napoli 1997:S20.

16. Schmitt DD, Bandyk DF, Pequet AJ, Towne JB: Bacterial adherence to vascular prostheses. A determinant of graft infectivity. J Vasc Surg 1986, 3(5):732-40.

17. Lamb JP, Vitale T, Kaminsky DL: Comparative evaluation of synthetic meshes used for abdominal wall replacement. Surgery 1983, 93(5):643-8.
18. Brown GL, Richardson JD, Malangoni MA, Tobin GR, Ackerman D, Polk HC Jr: Comparison of prosthetic materials for abdominal wall reconstruction in the presence of contamination and infection. Ann Surg 1985, 20 I(6):705-II.

19. Antonini G, Mariotti A, Ciaccarini R, Mercati U: Trattamento del laparocele con protesi in E-PTFE. Chir Generale 1992:67-70.

20. Becouam G, Szmil E, Leroux C, Arnaud JP: Surgical cure of postoperative eventrations with intraperitoneal implantation of dacron mesh. Apropos of 160 operated cases. J Chir 1996, I33(5):229-32.

21. Koehler RH, Begos D, Berger D, Carey S, LeBlanc K, Park A, Ramshaw B, Smoot R, Voeller G: Minimal adhesions to ePTFE mesh after laparoscopic ventral incisional hernia repair: reoperative findings in 65 cases. JSLS 2003, 7(4):335-40.
Publish with Bio Med Central and every scientist can read your work free of charge

"BioMed Central will be the most significant development for disseminating the results of biomedical research in our lifetime. "

Sir Paul Nurse, Cancer Research UK

Your research papers will be:

- available free of charge to the entire biomedical community

- peer reviewed and published immediately upon acceptance

- cited in PubMed and archived on PubMed Central

- yours - you keep the copyright

Submit your manuscript here:

http://www.biomedcentral.com/info/publishing_adv.asp
BioMedcentral 